\title{
Mineral Chemistry in Volcanic Rocks of Ore Deposit Nochun and Sarcheshmeh Copper Mine, Iran
}

\author{
Mehdi Abdollahi Riseh, Mansur Vosughi Abedini*, Mohammad Hashem Emami, \\ Seysd Jamal Sheikh Zakariaii
}

Department of Geology, Science and Research Branch, Islamic Azad University, Tehran, Iran

Email: *abdollahy_m@nicico.com

How to cite this paper: Riseh, M.A., Abedini, M.V., Emami, M.H. and Zakariaii, S.J.S. (2017) Mineral Chemistry in Volcanic Rocks of Ore Deposit Nochun and Sarcheshmeh Copper Mine, Iran. Open Journal of Geology, 7, 257-266.

https://doi.org/10.4236/ojg.2017.73018

Received: December 28, 2016

Accepted: March 19, 2017

Published: March 22, 2017

Copyright (๑) 2017 by authors and Scientific Research Publishing Inc. This work is licensed under the Creative Commons Attribution International License (CC BY 4.0).

http://creativecommons.org/licenses/by/4.0/

(c) (i) Open Access

\begin{abstract}
This paper studies on clinopyroxene, plagioclase of andesitic to dacite rocks of Nochun area to understand the geotectonic and geothermobarometry conditions. Eocene calc-alkaline volcanic rocks are exposed in Nochun that are near the Sarcheshmeh cooper mine. Volcanic rocks consist of andesitic to dacite rocks. Minerals in the volcanic rocks exhibit degrees of disequilibrium features. Plagioclase as dominant mineral in these rocks generally displays oscillatory zoning; sieves or dusty, cores are usually Ca-rich. Petrographic evidence and varying anorthite content (10\% to $90 \%)$ of plagioclase and temperature estimates of clinopyroxene indicated fractional crystallization condition later than hydrothermal alteration and partial metasomatism occurred. The varying content indicates that the parent's magma was generated from subalkaline composition and then hydrothermal alteration affected phenocryst minerals and matrix of andesitic to dacite rocks. The equilibration temperatures of clinopyroxene showed $\left(800^{\circ} \mathrm{C}-1200^{\circ} \mathrm{C}\right)$. Thus, in mafic minerals development of sieve textures in plagioclase, reaction rims, zoning and heterogeneity of plagioclase phenocrysts, the resorbed and embayed phenocrysts, unique composition of clinopyroxene phenocrysts; support fractional crystallization at deep reservoir and high pressure condition as an important process in the evolution of these rocks.
\end{abstract}

\section{Keywords}

Petrography, Fractional Crystallization, Sarcheshmeh Copper Mine

\section{Introduction}

Kerman region where Sarcheshmeh zone is located includes end part of Uremia- 
Dokhtar zone and generally petrologic units in this system (i.e. one of the most marvelous geological structures in Kerman region) comprises of clastic igneous and volcano clastic rocks from Eocene epoch and also in many regions, subvolcanic rocks (semi-deep plutonic) at age Oligo-Miocene and volcanic rocks of Quaternary sediments are accompanied with these formations. In this group, rocks have mainly volcanic origin. Due to lack of distinct fossil in rock units in major part of this system, age of this system has been approximated by petrologic relation and comparison with similar formations in other zones. Nonetheless, age of these sedimentary-volcanic formations has been considered from lower to upper Eocene and studied zone (Nochun) is also included as a part of this system. Sarcheshmeh mine is located $160 \mathrm{~km}$ distance from southwest of Kerman city, $50 \mathrm{~km}$ from south of Rafsanjan city, and $36 \mathrm{~km}$ from Pariz town. This mine is situated on geographical latitude (N: $\left.29^{\circ}, 58^{\prime}\right)$ and longitude (E: $\left.55^{\circ}, 53^{\prime}\right)$. Geology of zone comprises of Eocene volcanic-sedimentary group that is one of the most interesting geological structures in Kerman region. This system has northwest-southeast trend with length $500 \mathrm{~km}$ and at least $15 \mathrm{~km}$ diameter. The major part of this system is composed of different rocks with volcanic origin. The older rocks that have created basis for these structures have no facies in Sarcheshmeh zone. Plutonic and semi-deep rocks as well as dikes have crossed this group in many points. Due to absence of fossil in Sarcheshmeh zone, age of this system has been estimated by petrologic relations and comparison with similar structures in other zones. Based on this technique, age of this system has been considered as upper Eocene including transition from middle Eocene to upper Eocene. Sedimentary deposits from third and fourth geologic periods have been spread on Sarcheshmeh zone as well.

\subsection{Nochun Area}

The Nochun area is located near the Sarcheshmeh, a world class porphyry copper mine. The major towns close to the Nochun district are Rafsanjan, $60 \mathrm{~km}$ to the north, and Kerman, $90 \mathrm{~km}$ to the east-northeast. The morphology of the Nochun area includes a steeply incised mountainous terrain ranging in altitude between 2600 to $3040 \mathrm{~m}$. The region has an arid climate with a highest average temperature of $45^{\circ} \mathrm{C}$ during hot days in summer, but is cold to $-10^{\circ} \mathrm{C}$ during cold days in winter [1]. The dry season lasts from May to December and the wet season is between December and April. The total annual rainfall is $300 \mathrm{~mm}$ during the wet season.

\subsection{Literatures Review}

The geology of the Sarcheshmeh area was first studied by NICICO. The granodiorite dikes are commonly silicified and argillites. Siliceous veins are found within the granodiorite dikes and volcanic wall rocks. Pyrite, chalcopyrite, and chalcocite appear at shallow depth, where the siliceous veins are in contact with volcanic rocks [2].

Stresses the necessities of the present work are: 
- Study the primary and altered minerals, creating a detailed petrographic classification of the different rock types.

- Analyze the major and trace elements of rock types to find the geochemical signatures associated with the different rock types.

- Compare the lithogeochemistry and diagnostic mineral compositions of the Nochun area with the Sarcheshmeh porphyry copper deposit.

- Develop a genetic model for the Nochun area.

\section{Material and Methods}

120 samples were selected with respect to lack of iteration and given strength and thin section. In order to identify composition of constituent minerals in these rocks, 14 samples of regional rocks were selected. Electron-Probe Micro Analysis (EPMA) was done on 120 points at Iranian researcher centers for processing of minerals by camera (model: SX-100). Composition of constituent minerals on regional rocks was determined according to the given results from Electron-Probe Micro Analysis (EPMA) by diagrams for determination of mineral compositions presented by different researchers.

Most accepted values are within one standard deviation of the average. Backscattered electron (BSE) images of olivine, Clinopyroxene and Feldspar grains were taken to document zoning patterns. Element maps of $\mathrm{Mg}, \mathrm{Fe}, \mathrm{Al}$, and $\mathrm{Cr}$ of two zoned Cr-spinel grains were also obtained to document zoning patterns. The mineral analyses were processed with the program PET. Nomenclature of amphiboles and estimation of their $\mathrm{Fe}^{3+}$ contents follow the recommendations [3]. Mineral abbreviations are after Kretz [4].

The massive volcanic complex occurs through the east of the Sarcheshmeh cooper mine, Nochun area and corresponds to an Eocene volcanogenic eruption in the Urumieh-Dokhtar magmatic arc [2] [3]. This Eocene volcanic complex is the oldest rock unit cropping out at the Nochun area and mainly consists of fine-grained, dark-gray andesite to trachy-andesite. The trachy-andesite is particularly well developed at the contact with intrusive dikes, while the andesite is found to an extent beyond the intrusions through the east of the Nochun area. The volcanic complex is formed by steeply beds towards the northeast dipping. The volcanic complex covers $1.6 \mathrm{~km}^{2}$ of the Nochun area and shows a green alteration at the contact with the porphyritic intrusion. The copper carbonate veins developed through the volcanic rocks which are in contact with the intrusion. Several fragments (xenoliths) of volcanic rocks were found within the intrusion dikes. The western border of volcanic rock ends by breccia dikes, along the contact with porphyritic intrusion through the eastern portion of the Nochun area.

\section{Discussion}

\subsection{Petrography}

The dark gray, porphyritic andesite consists of fine to medium-grained pheno- 
crysts. The phenocrysts consist of plagioclase, pleochroic green amphibole, rarely clinopyroxene grains. Commonly, the amphibole phenocrysts are surrounded by a fine rim of Fe-oxide. The groundmass is dark gray containing variable amounts of plagioclase microliths, amphibole, cryptocrystalline material, magnetite, traces of opaque minerals. Commonly, the plagioclase phenocrysts crystallized early, followed by amphibole. (Figure 1(a) and Figure 1(b)).

The trachy-andesite is composed of abundant plagioclase, rare amphibole. The amount and crystal size of plagioclase increases in the trachy-andesite relative to the andesite rocks.

The dacite consists of phenocrysts set in a glassy matrix. They are accompanied by biotite, green hornblende and $\mathrm{K}$-feldspar. The glassy groundmass is dark and contains plagioclase microliths, quartz and feldspar fragments. The trace minerals include apatite, sphene, and fine-magnetite. (Figure 1(c) and Figure $1(d))$.

\subsection{Mineral Chemistry}

\subsubsection{Plagioclases}

Composition of this mineral is very sensitive to temperature, pressure, and the existing water content in molten material [5] [6]. Plagioclase is present as one of the major minerals in composition of volcanic rocks in Sarcheshmeh zone. Sur-

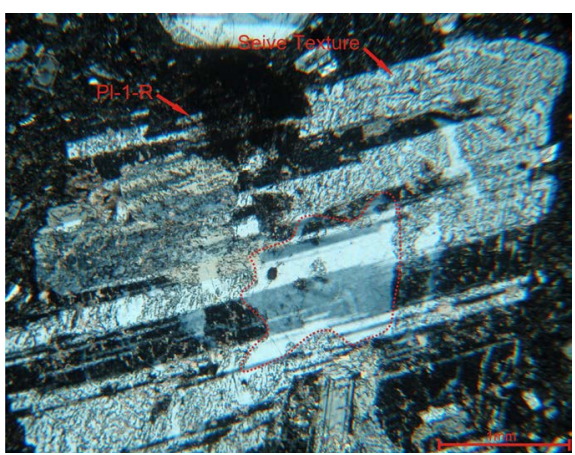

(a)

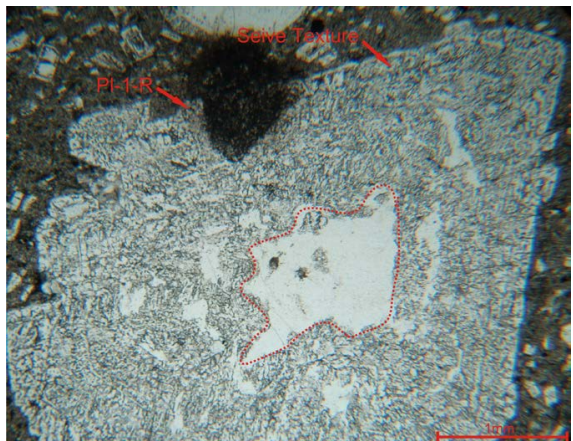

(c)

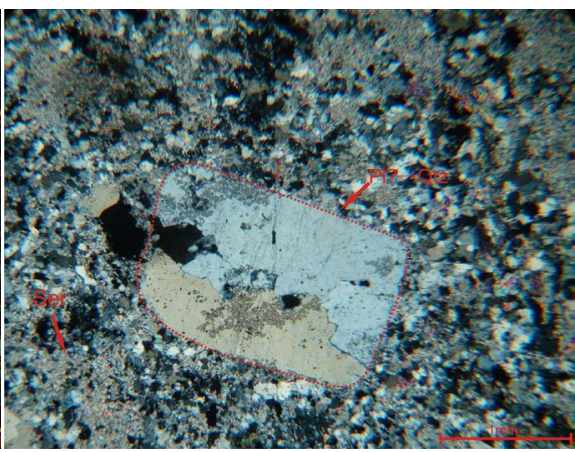

(b)

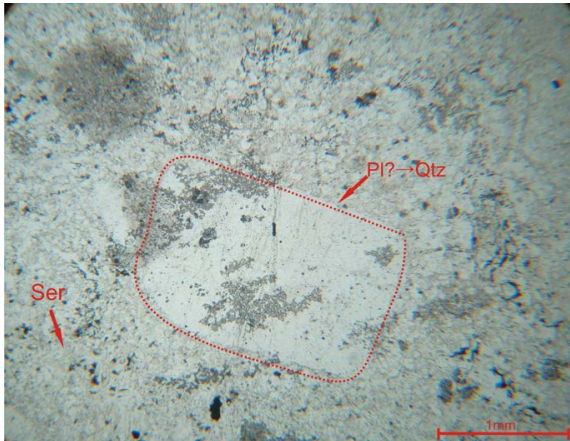

(d)

Figure 1. A view from thin sections of lavas. (a) Plagioclase phenocrysts in a and esite (XPL); (b) Plagioclase in andesite (PPL); (c) Plagioclase phenocrysts with microcrystalin texture in dacite (XPL); (d) Reaction and sieve-textured in Plagioclase phenocrysts, resorption-generated zone in dacite lavas (PPL). 
veying and study of microprobe analysis on plagioclase mineral in regional rocks shows that some of plagioclase minerals indicate wet calcic compounds so that the quantities of calcium is more increased from margin to margin in these minerals. We utilized triangular diagram of Or-Ab-An to determine composition of plagioclase minerals in regional rocks. Based on these diagrams, existing plagioclases in regional rocks show wide composition from albite to bitonit. Plagioclases with bitonit composition indicate compounds belonging to wet calcic crystals. Likewise, results of conducted analyses on a pyroclastic sample indicate that plagioclase minerals in this sample possess calcic property and show composition of labradorite to bitonit. The most An-rich plagioclase phenocrysts occur in the Andesitic rocks, while the most An-poor crystals are from the dacite porphyritic rocks.

Sieve texture and zonation of plagioclase is noticeable in these volcanic rocks (Figure 2). This may be interpreted as resulting from either partial dissolution during the magma process [7], or a decompression effect [8]. Tsuchiyama [9] concluded from experimental data that "these textures were closely related to temperature and chemical compositions)" [10]. Plagioclase phenocrysts in lavas develop a resorption zone in response to different temperature and composition of surrounding melt. Then the outer rim crystallizes with composition of new magma [11] Table 1.

\subsubsection{Pyroxenes}

Clinopyroxene mineral is one of the paramount minerals in determining position of formation and geodynamic environment in igneous rocks, especially types of volcanic rocks. Approximation of temperature and pressure of volcanic

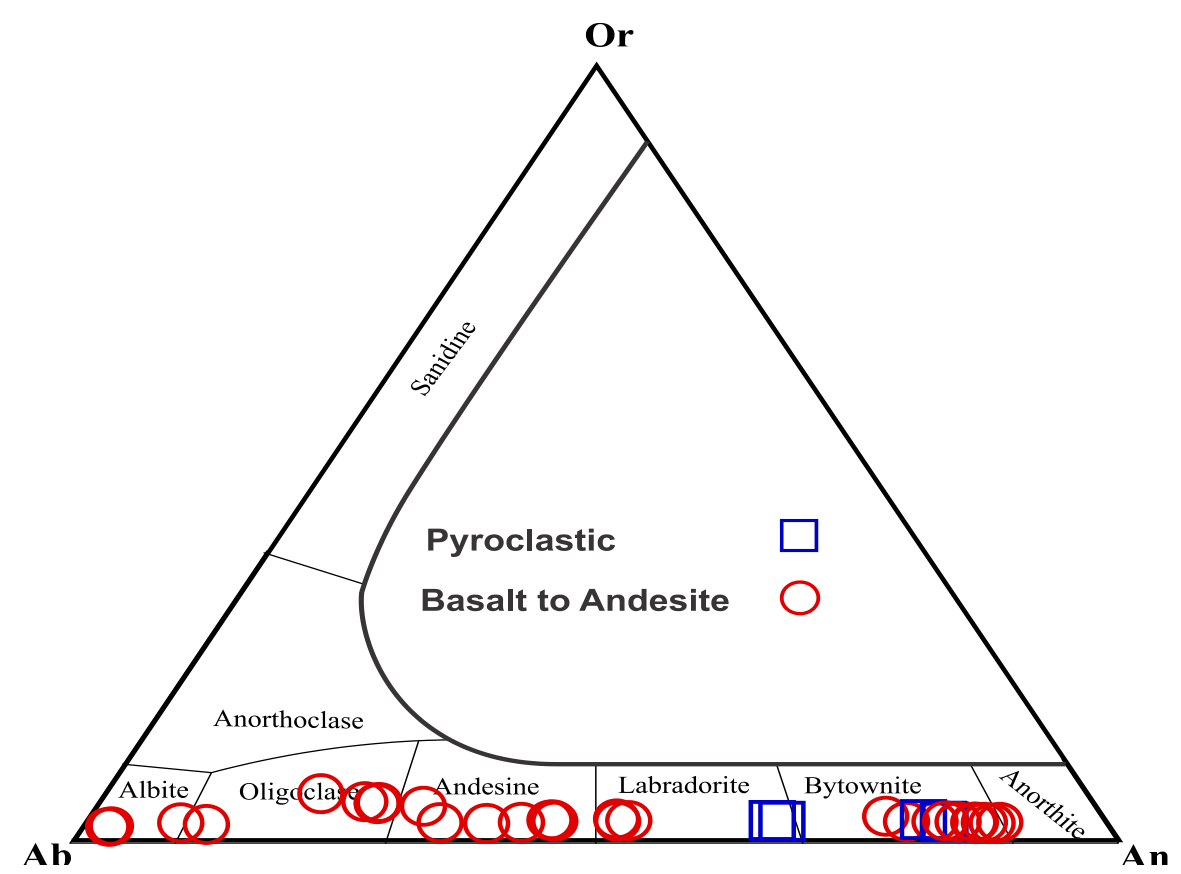

Figure 2. Diagram of determination of plagioclase composition in rocks of the zone: Plagioclase composition in rocks of this zone covers wide range from albite to bitonit. 
Table 1. The results of microprobe analysis on plagioclase in Nochun zone.

\begin{tabular}{|c|c|c|c|c|c|c|c|c|c|c|c|c|}
\hline Point. No & $\mathrm{SiO}_{2}$ & $\mathrm{TiO}_{2}$ & $\mathrm{Al}_{2} \mathrm{O}_{3}$ & $\mathrm{FeO}$ & $\mathrm{MnO}$ & $\mathrm{MgO}$ & $\mathrm{CaO}$ & $\mathrm{Na}_{2} \mathrm{O}$ & $\mathrm{K}_{2} \mathrm{O}$ & An & $\mathrm{Ab}$ & Or \\
\hline HH1 & 46.87 & 0.04 & 32.82 & 0.6 & 0.01 & 0.1 & 17.33 & 1.97 & 0.05 & 82.7 & 17 & 0.3 \\
\hline HH2 & 47.75 & 0.03 & 32.62 & 0.63 & 0.01 & 0.13 & 16.91 & 2.31 & 0.05 & 80 & 19.8 & 0.3 \\
\hline HH3 & 55.19 & 0.06 & 27.85 & 0.7 & 0 & 0.05 & 11.13 & 5.65 & 0.23 & 51.5 & 47.3 & 1.3 \\
\hline HH4 & 44.77 & 0.01 & 33.57 & 0.57 & 0.01 & 0.07 & 18.82 & 1.17 & 0.03 & 89.7 & 10.1 & 0.2 \\
\hline HH5 & 44.71 & 0.02 & 33.58 & 0.65 & 0.01 & 0.07 & 18.64 & 1.26 & 0.01 & 89.1 & 10.9 & 0.1 \\
\hline HH6 & 50.13 & 0.05 & 29.31 & 0.94 & 0.01 & 0.16 & 14.92 & 2.28 & 0.15 & 77.6 & 21.5 & 0.9 \\
\hline HH7 & 65.5 & 0 & 21.21 & 0.18 & 0 & 0.01 & 2.76 & 10.93 & 0.1 & 12.2 & 87.3 & 0.5 \\
\hline HH8 & 66.12 & 0 & 20.36 & 0.1 & 0 & 0 & 2.2 & 11.36 & 0.14 & 9.6 & 89.7 & 0.7 \\
\hline HH9 & 68.1 & 0 & 19.84 & 0.02 & 0 & 0.01 & 0.21 & 12.63 & 0.08 & 0.9 & 98.7 & 0.4 \\
\hline HH10 & 67.45 & 0 & 20.08 & 0.03 & 0.02 & 0 & 0.16 & 13.02 & 0.09 & 0.7 & 98.9 & 0.4 \\
\hline HH11 & 67.99 & 0 & 19.78 & 0.07 & 0.01 & 0 & 0.22 & 12.43 & 0.11 & 1 & 98.5 & 0.6 \\
\hline HH12 & 62.45 & 0.02 & 23 & 0.15 & 0 & 0 & 4.67 & 9.11 & 1 & 20.9 & 73.8 & 5.3 \\
\hline HH13 & 60.87 & 0.01 & 24.13 & 0.15 & 0 & 0 & 5.86 & 8.22 & 0.76 & 27.1 & 68.7 & 4.2 \\
\hline НH14 & 60.87 & 0 & 23.62 & 0.18 & 0.01 & 0 & 5.67 & 8.56 & 0.8 & 25.6 & 70.1 & 4.3 \\
\hline HH15 & 59.7 & 0 & 25.1 & 0.13 & 0 & 0 & 7 & 7.9 & 0.61 & 31.8 & 64.9 & 3.3 \\
\hline HH16 & 60.93 & 0.03 & 24.04 & 0.16 & 0.01 & 0 & 5.92 & 8.37 & 0.76 & 26.9 & 68.9 & 4.1 \\
\hline HH17 & 60.49 & 0.02 & 24.22 & 0.16 & 0 & 0 & 5.91 & 8.36 & 0.75 & 26.9 & 69 & 4.1 \\
\hline HH18 & 57.11 & 0.09 & 26.33 & 0.8 & 0 & 0.08 & 9.76 & 6.43 & 0.28 & 44.9 & 53.5 & 1.5 \\
\hline HH19 & 54.78 & 0.09 & 26.96 & 0.84 & 0 & 0.15 & 11.24 & 5.44 & 0.19 & 52.7 & 46.2 & 1.1 \\
\hline $\mathrm{HH} 20$ & 56.72 & 0.08 & 26.49 & 0.7 & 0.01 & 0.08 & 9.96 & 6.44 & 0.25 & 45.5 & 53.2 & 1.4 \\
\hline HH21 & 59.14 & 0.02 & 21.05 & 0.11 & 0.01 & 0 & 8.65 & 8.93 & 0.25 & 34.5 & 64.4 & 1.2 \\
\hline HH22 & 57.41 & 0.05 & 26.35 & 0.36 & 0 & 0 & 9.1 & 6.71 & 0.22 & 42.3 & 56.5 & 1.2 \\
\hline $\mathrm{HH} 23$ & 54.77 & 0.05 & 27.93 & 0.43 & 0.01 & 0 & 11.14 & 5.63 & 0.17 & 51.7 & 47.3 & 0.9 \\
\hline $\mathrm{HH} 24$ & 56.06 & 0.04 & 26.94 & 0.4 & 0 & 0.03 & 9.76 & 6.36 & 0.28 & 45.2 & 53.3 & 1.5 \\
\hline HH25 & 57.7 & 0.05 & 25.76 & 0.31 & 0.01 & 0 & 8.45 & 7.17 & 0.2 & 39 & 59.9 & 1.1 \\
\hline HH26 & 50.33 & 0.05 & 29.13 & 1 & 0.01 & 0.06 & 14.06 & 3.78 & 0.14 & 66.7 & 32.5 & 0.8 \\
\hline HH27 & 46.33 & 0.02 & 32.13 & 0.72 & 0.02 & 0.05 & 17.24 & 1.85 & 0.05 & 83.5 & 16.2 & 0.3 \\
\hline HH28 & 46.9 & 0.02 & 31.65 & 0.68 & 0 & 0.1 & 16.93 & 2.07 & 0.09 & 81.5 & 18 & 0.5 \\
\hline HH29 & 45.85 & 0.02 & 31.79 & 0.64 & 0 & 0.05 & 17.34 & 1.84 & 0.04 & 83.7 & 16.1 & 0.2 \\
\hline НH30 & 50.3 & 0.04 & 29.25 & 0.94 & 0.01 & 0.09 & 14.15 & 3.65 & 0.12 & 67.7 & 31.6 & 0.7 \\
\hline HH31 & 46.02 & 0.02 & 32.33 & 0.62 & 0.02 & 0.05 & 17.48 & 1.84 & 0.06 & 83.7 & 15.9 & 0.3 \\
\hline HH32 & 45.01 & 0.03 & 32.74 & 0.63 & 0.01 & 0.04 & 18.24 & 1.55 & 0.03 & 86.5 & 13.3 & 0.2 \\
\hline НH33 & 45.36 & 0 & 33.09 & 0.59 & 0.01 & 0.02 & 18.18 & 1.41 & 0.03 & 87.5 & 12.3 & 0.2 \\
\hline HH34 & 45.77 & 0.02 & 32.65 & 0.67 & 0 & 0.03 & 17.63 & 1.7 & 0.04 & 84.9 & 14.8 & 0.2 \\
\hline НH35 & 45.81 & 0.05 & 32.76 & 0.61 & 0.03 & 0.06 & 17.5 & 1.47 & 0.03 & 86.7 & 13.2 & 0.2 \\
\hline
\end{tabular}

rocks is also one of other cases that indicate importance of pyroxene minerals. In addition, composition of clinopyroxene minerals is a function of chemical compound and ambience to form builder of their magma and it can propose valuable information about tectonic environment in formation of rocks to us [12].

Based on results of microprobe analysis, all of analyzed pyroxene minerals are located within calcic limit in diagram of Q-J classification. Similarly, according to triangular terminological chart for pyroxenes, the pyroxene mineral is com- 
posed of diopside and augite types in these rocks (Figure 3). Generally, mineralography composition of this mineral is almost fixed in regional rocks and it varies approximately from $\mathrm{Wo}_{27.65} \mathrm{En}_{40.16} \mathrm{Fs}_{8.82}$ to $\mathrm{Wo}_{47.27} \mathrm{En}_{47.01} \mathrm{Fs}_{29.04}$. According to diagram, most of samples have move away from territory of alkaline rocks due to shortage of $\mathrm{TiO}_{2}$ and they have been located within range of calc-alkaline rocks. Likewise, based on triangular diagram of $\mathrm{TiO}_{2}-\mathrm{SiO}_{2} / 100-\mathrm{Na}_{2} \mathrm{O}$, the studied clinopyroxene minerals show property of magmatic arcs in terms of tectonomagmatic environment (Figure 4). The low quantity of $\mathrm{TiO}_{2}$ in structural formula of the studied pyroxenes on the one hand and high rate of $\mathrm{SiO}_{2}$ on the

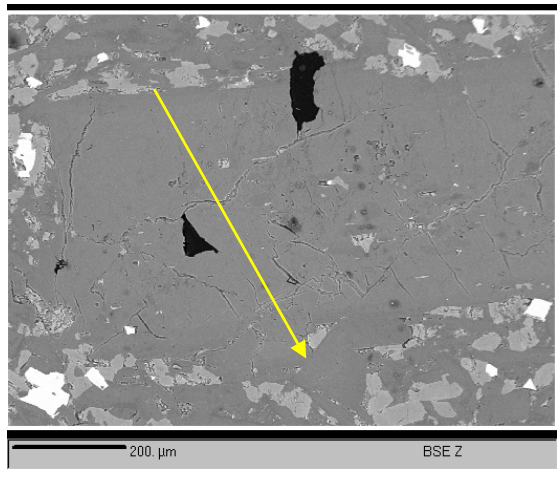

(a)

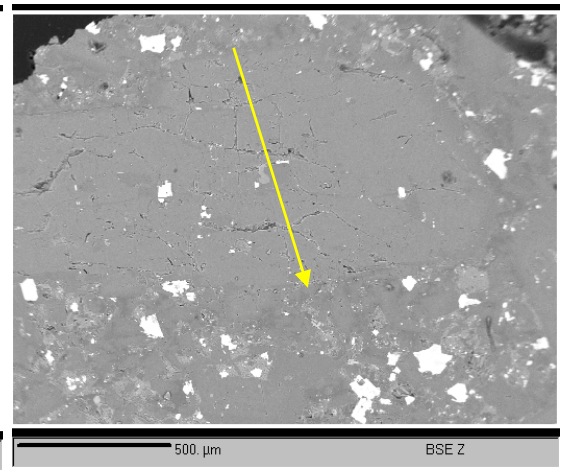

(b)

Figure 3. Plagioclase chemistry: (a) Backscatter image showing the traverse points that were analyzed, and (b) Compositional zoning of plagioclase.
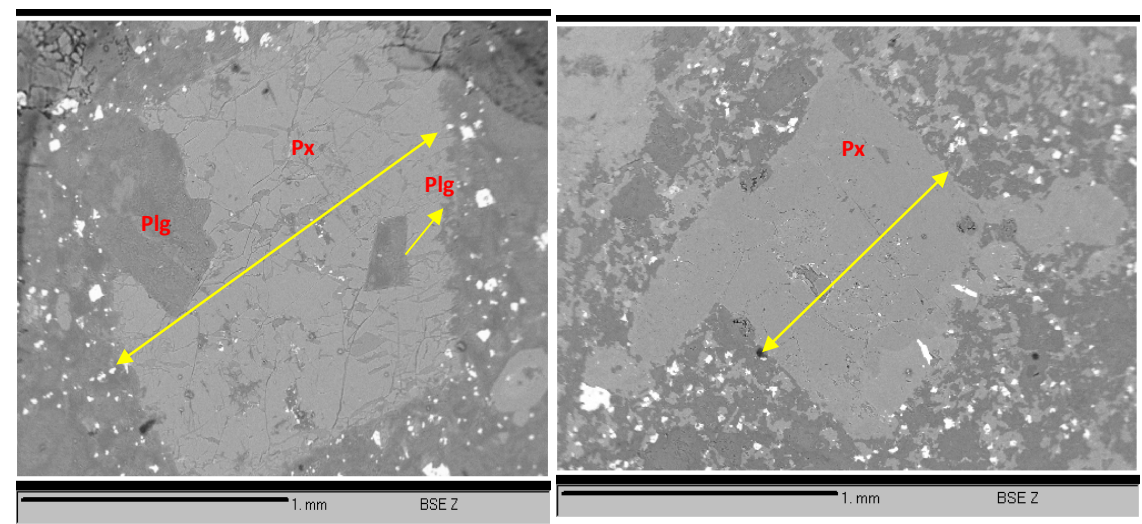

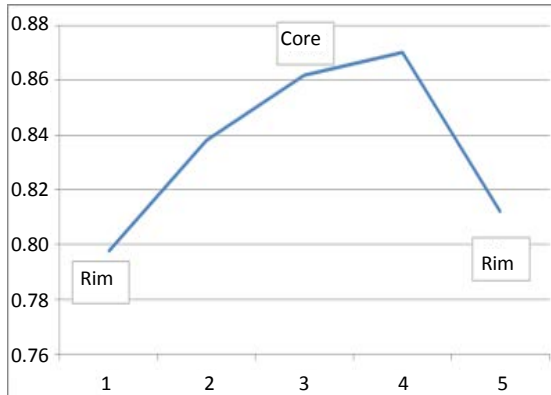

(a)

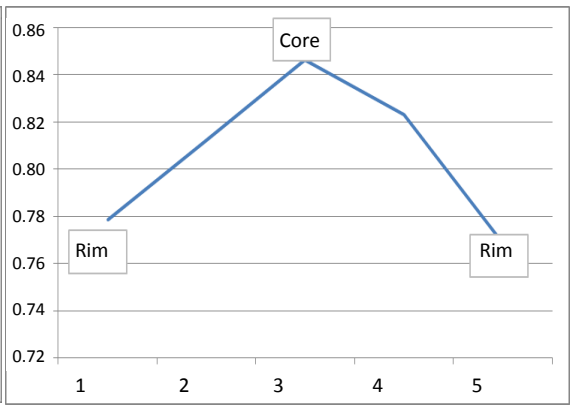

(b)

Figure 4. Clinopyroxene chemistry: (a) Backscatter image showing the traverse points that were analyzed; and (b) Compositional zoning of clinopyroxene. 
other hand may indicate property of the existing pyroxenes in igneous rocks in volcanic arcs [13]. Microprobe analytical results for pyroxene are listed in Figure 5 and Table 2.

Table 2. The results microprobe analysis on pyroxene at Nochun zone.

\begin{tabular}{|c|c|c|c|c|c|c|c|c|c|}
\hline Point. No & $\mathrm{SiO}_{2}$ & $\mathrm{TiO}_{2}$ & $\mathrm{Al}_{2} \mathrm{O}_{3}$ & $\mathrm{Cr}_{2} \mathrm{O}_{3}$ & $\mathrm{FeO}$ & $\mathrm{MnO}$ & $\mathrm{MgO}$ & $\mathrm{CaO}$ & $\mathrm{Na} 2 \mathrm{O}$ \\
\hline HS1 & 49.61 & 0.56 & 5.68 & 0.012 & 6.04 & 0.13 & 15.17 & 22.75 & 0.42 \\
\hline HS2 & 49.96 & 0.48 & 5.63 & 0.14 & 5.82 & 0.11 & 15.25 & 23.09 & 0.45 \\
\hline HS3 & 50.77 & 0.48 & 4.65 & 0.32 & 5.52 & 0.15 & 15.65 & 22.74 & 0.33 \\
\hline HS4 & 49.72 & 0.55 & 5.48 & 0.2 & 5.89 & 0.13 & 15.45 & 22.67 & 0.47 \\
\hline HS5 & 51.66 & 0.64 & 1.86 & 0.05 & 9.47 & 0.28 & 15.68 & 20.34 & 0.43 \\
\hline HS6 & 51 & 0.49 & 3.63 & 0 & 7.45 & 0.2 & 15.34 & 22.29 & 0.3 \\
\hline HS7 & 49.41 & 0.85 & 5.9 & 0 & 8.25 & 0.23 & 13.84 & 22.23 & 0.4 \\
\hline HS8 & 50.05 & 0.88 & 5.4 & 0 & 8.02 & 0.15 & 14.11 & 22.35 & 0.46 \\
\hline HS9 & 49.24 & 0.81 & 5.12 & 0 & 8.22 & 0.18 & 14.07 & 22.76 & 0.4 \\
\hline HS10 & 49.28 & 0.85 & 6 & 0 & 8.05 & 0.2 & 14.09 & 22.22 & 0.44 \\
\hline HS11 & 51.34 & 0.75 & 1.85 & 0.01 & 13.78 & 0.41 & 15.89 & 16.6 & 0.26 \\
\hline HS12 & 52.55 & 0.47 & 1.95 & 0.13 & 9.38 & 0.34 & 16.35 & 18.93 & 0.51 \\
\hline HS13 & 51.52 & 0.6 & 2.72 & 0.33 & 8.81 & 0.25 & 15.94 & 19.79 & 0.44 \\
\hline HS14 & 52.23 & 0.55 & 1.72 & 0.05 & 9.98 & 0.28 & 16.74 & 18.47 & 0.55 \\
\hline HS15 & 51.99 & 0.48 & 1.89 & 0.02 & 10.2 & 0.61 & 14.16 & 21.17 & 0.52 \\
\hline HS16 & 52.05 & 0.49 & 1.87 & 0 & 10.75 & 0.62 & 14.81 & 20.33 & 0.38 \\
\hline HS17 & 51.57 & 0.44 & 1.54 & 0 & 10.25 & 0.63 & 15.44 & 20.66 & 0.43 \\
\hline HS18 & 51.62 & 0.54 & 2.25 & 0 & 10.64 & 0.54 & 14.96 & 19.87 & 0.4 \\
\hline HS19 & 48.98 & 0.7 & 4.39 & 0 & 15.86 & 0.66 & 13.27 & 11.79 & 1.02 \\
\hline HS20 & 49.04 & 0.68 & 4.38 & 0.06 & 8.62 & 0.25 & 14.3 & 21.19 & 0.36 \\
\hline HS21 & 50.16 & 0.51 & 3.4 & 0.17 & 7.3 & 0.18 & 15.17 & 22.23 & 0.28 \\
\hline HS22 & 50.42 & 0.62 & 2.58 & 0.04 & 9.59 & 0.27 & 15.46 & 19.95 & 0.17 \\
\hline HS23 & 50.48 & 0.57 & 2.56 & 0.08 & 9.76 & 0.28 & 15.71 & 19.76 & 0.36 \\
\hline HS24 & 49.39 & 0.68 & 4.26 & 0.03 & 8.61 & 0.21 & 14.62 & 21.3 & 0.2 \\
\hline
\end{tabular}

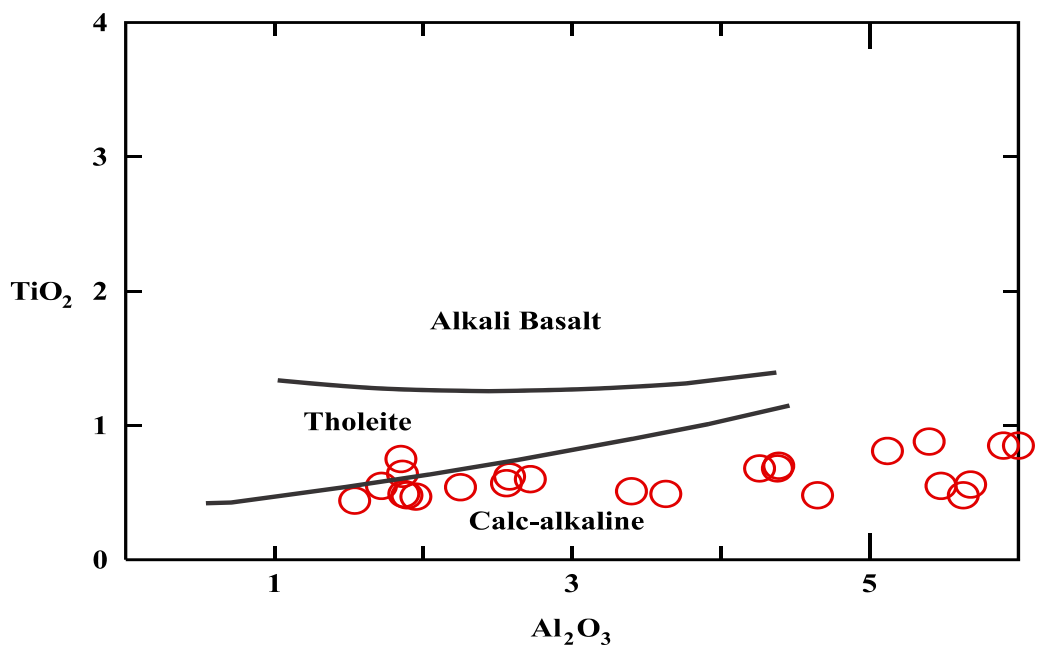

Figure 5. $\mathrm{TiO}_{2}$ v. $\mathrm{Al}_{2} \mathrm{O}_{3}$ binary diagram for pyroxene. 


\section{Conclusion}

The studied rocks in Nochun zone include extrusive and intrusive igneous rocks. The major ores in studied sections of Nochun zone consist of pyrite, chalcopyrite, and magnetite. The subsidiary minerals also include chalcocite, covellite, bornite, and hematite. We may find it by comparing mineralization of magnetite and hematite in Nochoon with Sarcheshmeh zone that magnetite mineral is less spread in background rock in Nochoon. Alternately, rate of conversion of magnetite to hematite is higher in Nochoon than in Sarcheshmeh zone and magnetite is more under influence of hydrothermal solutions in Nochoon. It is characterized by comparison of pyrite and chalcopyrite mineralization in Nochoon versus Sarcheshmeh that mineralization is different in these two ores with each other in terms of paragenetic sequence and various generations. Minerals in the volcanic rocks exhibit degrees of disequilibrium features. Plagioclase as dominant mineral in these rocks generally displays oscillatory zoning; sieves or dusty, cores are usually Ca-rich. Petrographic evidence and varying anorthite content of plagioclase and temperature estimates of clinopyroxene indicated fractional crystallization condition later than hydrothermal alteration and partial metasomatism occurred. The varying content indicates that the parent's magma was generated from subalkaline composition and then hydrothermal alteration affected phenocryst minerals and matrix of andesitic to dacite rocks.

\section{References}

[1] Shahabpour, J. (1982) Aspects of Alteration and Mineralization at the Sar-Cheshemeh Copper-Molybdenum Deposit. Ph.D. Thesis, Leeds Universtiy, Kerman, Iran.

[2] Bazin, D. and Hübner, H. (1969) Copper Deposits in Iran. Geological Survey of Iran, Tehran, $232 \mathrm{p}$.

[3] Leake, B.E. (1978) The Nomenclature of Amphiboles. Mineralogical Magazine, 42, 533-563. https://doi.org/10.1180/minmag.1978.042.324.21

[4] Kretz, R. (1983) Symbole for Rock Forming Minerals. American Mineralogist, 68, 277-279.

[5] Nelson, S.T. and Montana, A. (1992) Sieved Textured Plagioclase in Volcanic Rocks Produced by Rapid Decompression. American Mineralogist, 77, 1242-1249.

[6] Nixon, G.T. (1988) Petrology of the Younger Andesites and Dacites at Iztaccihuatl Volcano, Mexico: I. Disequilibrium Phenocryst Assemblages as Indicators of Magma Chamber Processes. Journal of Petrology, 29, 213-264.

https://doi.org/10.1093/petrology/29.2.213

[7] Feeley, T.C. and Dungan, M.A. (1996) Compositional and Dynamic Controls on Mafic-Silicic Magma Interactions at Continental Arc Volcanoes; Evidence from Cordon El Guadal, Tatara-San Pedro Complex, Chile. Journal of Petrology, 37, 1547-1577. https://doi.org/10.1093/petrology/37.6.1547

[8] Dachs, E. (1998) PET: Petrological Elementary Tools for Mathematica. Computers and Geoscience, 24, 219-235.

[9] Tsuchiyama, A. (1985) Dissolution Kinetics of Plagioclase in the Melt of the System Diopside-Albite-Anorthite, and Origin of Dusty Plagioclase in Andesites. Contributions to Mineralogy and Petrology, 89, 1-16. https://doi.org/10.1007/BF01177585 
[10] Ghahroudi-Tali, M., Abdoli, E. and Nezammahalleh, M.A. (2013) Geomorphological and Sedimentological Evidence of Alpine Glaciers in the Zagros Mountains, Dinevar, Iran. Journal of Tethys, 1, 85-95.

[11] Halsor, S.P. and Rose, W.I. (1991) Mineralogical Relations and Magma Mixing in Calc-Alkaline Andesites from Lake Atitlan, Guatemala. Mineralogy and Petrology, 45, 47-67. https://doi.org/10.1007/BF01164502

[12] Ewart, A. (1982) The Mineralogy and Petrology of Tertiary-Recent Orogenic Volcanic Rocks: With a Special Reference to the Andesitic-Basaltic Compositional Range. In: Thorpe, R.S., Ed., Andesites: Orogenic Andesites and Related Rocks, Wiley, Chichester, 25-95.

[13] Nixon, G.T. and Pearce, T.H. (1987) Laser-Interferometry of Oscillatory Zoning in Plagioclase: The Record of Magma Mixing and Phenocryst Recycling in Calc-Alkaline Magma Chambers, Iztaccihuatl Volcano, Mexico. American Mineralogist, 72 , 1144-1162.

Submit or recommend next manuscript to SCIRP and we will provide best service for you:

Accepting pre-submission inquiries through Email, Facebook, LinkedIn, Twitter, etc. A wide selection of journals (inclusive of 9 subjects, more than 200 journals)

Providing 24-hour high-quality service

User-friendly online submission system

Fair and swift peer-review system

Efficient typesetting and proofreading procedure

Display of the result of downloads and visits, as well as the number of cited articles

Maximum dissemination of your research work

Submit your manuscript at: http://papersubmission.scirp.org/

Or contact ojg@scirp.org 